\title{
Gender in a Land-Based Theology
}

\author{
Matt Tomlinson \\ Australian National University
}

\begin{abstract}
In Fijian Methodist discourse, the vanua (land and people) is often characterised as the foundation of the traditional order and all it entails. Indigenous theologians attend to the vanua in novel ways, especially as it is paired in a half-complementary, half-oppositional way to Christianity. The question of whether the vanua might be understood in gendered terms highlights a gap between theoretically universal values and practically patriarchal norms. In this article, I discuss several innovative thinkers on this subject: (1) women in the 'Weavers' theological collective; (2) the Methodist theologian and former church President Ilaitia Sevati Tuwere; and (3) a female Methodist minister, Tima, whom I interviewed in 2009. I focus especially on Tuwere's description of the 'feminine face' of the vanua and Tima's continual and wrenching conflict with the church's maledominated hierarchy. Whereas Tuwere uses a quasi-feminist Christian theology to reconcile Christianity and the vanua in terms of gender, Tima implies that her experiences of conflict with older men demonstrate how Christianity and the vanua might not be fully reconcilable.
\end{abstract}

\section{KEYWORDS}

Theology, feminism, land, Fiji, Christianity 
What is at stake when scholars speak of land in gendered terms? I use the term 'land' and not 'nation' deliberately. It is well established by historians that nationalist projects can be motivated by appeals to gendered embodiments of the nation: for example, the Prussian Fatherland which demands manly sacrifice (Hagemann 2000), or Mother India and Mother Tamil, goddesses who foster 'sentiments of longing and belonging that a scientific map cannot possibly generate' (Ramaswamy 2001:110). But land itself, regardless of national boundaries, can also be represented as gendered. In religious and political terms, what is gained or lost in such representations? Anthropologically, how do representations of land as gendered articulate with broader claims about human and divine power and purpose?

To answer such questions, I analyse Fijian Methodist theological discourse on land and gender. I focus on theology for three reasons. First, several authors have recently built a compelling case for why social scientists ought to pay serious and sympathetic attention to it: namely, to understand how secular social theory grounds itself in the rejection of preexisting theological principles (Milbank 2006), to discuss others' moral systems in terms that resonate appropriately (Priest 2000), and, for cultural anthropologists, to reinvigorate a commitment to understanding 'real otherness at the fundamental level of social ontology' (Robbins 2006:292; see also Engelke and Robbins 2010). Second, 99 per cent of indigenous Fijians are members of Christian churches, and the theologians I discuss in this article are well attuned to matters of public interest. Land is a prominent and emotionally potent topic in religious and political discourse in Fiji, and theological explorations of land are grounded in popular sentiments. Third, the Fijian term for land, vanua, is also a term for people, specifically people within a chiefdom. Vanua is both territory and polity, the landscape and 
seascape as well as the people who belong to a place, and this twinned significance expands into a constellation of meanings: the vanua is associated with tradition, security and well-being. As Pio Manoa puts it, vanua 'denotes first land, plot, space, place, territory, location, area, country. And it also refers to the group of people that belong to the allotted territory, their social structure, their cultural moorings and relational orientations, their locus of significance and identity, their pragmatic socioeconomic unit, their territorial ascription, their enabling environment and enabling referent of gifting, their source and focus of obligation, their hope of stable living and rootedness' (2010:79; see also Ravuvu 1983:76). As a result, in indigenous Fiji, one often cannot talk about land without talking about people, and it is difficult to talk about people without talking about land. This intimate connection lends itself readily to spiritual imaginations of eternal homelands, divine gifts of territory, and an enchanted landscape. In the first part of this article, I examine the writings of a women's theological group named 'Weavers' which was established by the South Pacific Association of Theological Schools. I focus on the work of Lesila Raitiqa, who most directly addresses the topic of gender and the vanua. Next I turn to llaitia Sevati Tuwere, a theologian who has also served as president of the Methodist Church in Fiji, and who devotes much of his scholarship to understanding the vanua in theological terms. In the third section, I consider the personal narrative of Tima, an ordained Methodist minister who has struggled against chiefs and senior church authorities in her career. These theologians differ in their understandings of interconnections between gender and the vanua, but all of them treat the vanua as a core topic indigenous Fijians must think about in new ways to articulate hopeful futures. 


\section{VANUA IN THE WORK OF WEAVERS}

Fijian Methodists' contemporary understandings of the vanua must be seen in the context of the nation's four coups since 1987. The first three coupstwo in 1987 led by Sitiveni Rabuka, one in 2000 led by George Speightgained popular support from many indigenous Fijians because of leaders' public appeals to defend the vanua against supposed foreign threats. The vanua, as both land and people, is often thought to be in peril: land might be alienated and sold off, and people might lose or forget their ancestral traditions. During the first three coups, when anxieties about threats to the vanua were stoked by some indigenous political leaders, many Methodist Church authorities either implicitly or explicitly supported the coups as acts of defending the vanua. Indeed, the army colonel who led the 1987 coups, Rabuka, was a lay Methodist preacher who enjoyed delivering sermons based on Lamentations 5:2, 'Our inheritance has been turned over to strangers, our homes to aliens' (Heinz 1993:433). The fourth coup, in 2006, was an entirely different affair. Military commander Voreqe Bainimarama deposed an indigenous Fijian-dominated government that had popular support, and later shut down some of the Methodist Church's key activities; I discuss these events below.

Claims about the vanua are not necessarily claims about the nation. Indeed, as Teresia Teaiwa (2000) has written, 'The problem with Fijian nationalism is that there is no Fijian nation' (cf. Kelly and Kaplan 2001:198; Tuwere 2002:30-31). She explains that indigenous disputes over leadership—namely, rivalries between chiefdoms—have destabilised the country more than conflicts between Fiji's ethnic groups have. (The most prominent ethnic division is between indigenous Fijians and Indo-Fijians, who are citizens of South Asian descent). Her implication is that the social unit of Fiji coheres neither as a single indigenous polity nor as a 
multicultural nation-state. In response to perceived social fragmentation, some indigenous politicians and Christian church leaders over the past several decades have called for Fiji to be formally declared a Christian state, revealing their desire to tie together indigenous identity, Christian identity, and political sovereignty as tightly as possible (Ryle 2001, 2010).

As the Anglican theologian Winston Halapua observes, ideologies of the vanua and tradition have been given a masculine and militaristic emphasis in Fiji (Halapua 2003). He notes that conceptions of the vanua as a spiritual and holistically interconnected union of people and place have inspired the creation of new political institutions such as the Great Council of Chiefs, the Alliance Party of Ratu Mara (independent Fiji's first prime minister), the Soqosoqo ni Vakavulewa ni Taukei party (itself a creation of the Great Council of Chiefs) after the coups of 1987, and the Soqosoqo Duavata ni Lewenivanua party after the coup of 2000 , all established with the 'aim to project the essence of vanua' (Halapua 2003:84-85). Although the land of Fiji is not specifically described as male in Fijian discourse, it is considered by many Methodists to be God's gift to indigenous Fijians, it is usually ruled and represented by male chiefs, and God is generally understood in masculine terms as the highest turaga (lord, chief) and universal father. Such masculine models prompt my question about the implications of describing the vanua in gendered terms.

In 1989, the Suva-based South Pacific Association of Theological Schools established a group named Weavers in order 'to support Pacific Islander women in their efforts to do theology, and to advocate their inclusion in the (still mostly male-dominated) theological institutions of the region' (Johnson 2003:12-13; see also Samate 2011:74-75). In April 2001, Weavers convened a writing workshop which resulted in the publication of a book titled Weavings featuring chapters by authors from Aotearoa/New 
Zealand, Fiji, Kanaky/New Caledonia, Kiribati, Maohi Nui/French Polynesia, Niue, Samoa, Solomon Islands, Tonga, and Vanuatu (Johnson and Filemoni-Tofaeono 2003). In this article, I focus on the contributions from Fijian Methodists for two reasons. First, the Methodist Church has enormous social and political influence in Fiji. Second, members of the church tend to identify the vanua as a key component of both indigenous and Christian identity: 'The vanua and the Methodist church are regarded as inseparable by most Methodist church members' (Degei 2007:vi). Other Fijian Christian denominations do not necessarily place the same emphasis on the vanua or evaluate its worth so positively, as Rachel Morgain observes in her contribution to this issue (see also Ryle 2001:298n92).

Two Bible verses that are invoked by several of the authors in Weavings are Genesis 1:26, in which God makes humanity in the divine 'image' and 'likeness', and Galatians 3:28, in which Paul asserts 'There is neither Jew nor Greek, there is neither bond nor free, there is neither male nor female: for ye are all one in Christ Jesus.' The authors who cite these verses (not only the Fijian authors) read Oceanic societies' patriarchal tendencies against this grain. For example, Meresiana Soronakadavu notes that 'Like many of her Pacific Islander sisters, the traditional Fijian woman has neither a public place nor a voice in public decision-making.... Women are seen as inferior to men and always under the leadership of men' (2003:161). Similarly, Ilisapeci Meo writes, 'The societies of the Pacific Islands are all, in varying degrees, patriarchal. This patriarchal structure has been encouraged and strengthened by Christianity, thereby further legitimizing the oppression of women' (2003:151; see also Meo 2012, and the nuanced discussion by Nicole George in this issue).

In reflecting on society and tradition, most of the Fijian Methodist authors do not explicitly discuss the land itself, although two refer to Fiji as 
a lost paradise, one in a poem and one in a prayer (Sovaki 2003; CostelloOlsson 2003), and in the book's concluding chapter, Sainimere Niukula describes all of nature as a divine message (2003:213). In an earlier publication by Weavers, papers from a 1995 meeting that were gathered in an issue of the Pacific Journal of Theology, Losena Tubanavau-Salabula laments environmental damage in Oceania and proposes that women form a ritual 'chain of meditation ... every Wednesday at noon to pray for our mother earth' (1996:64). Aside from these scattered examples, most Fijian Methodist authors do not directly address the topic of the vanua.

The key exception is Lesila Raitiqa, who describes the biblical heroine Ruth as 'redeemer of the land'. In the biblical story, Ruth, a widow from Moab, insists on following her late husband's mother to Bethlehem rather than returning to her own mother's household. In modern terms, she converts to Judaism, joining the family line that will lead in three generations to King David.

At the beginning of the book of Ruth, a man named Elimelech and his family leave Bethlehem to live in Moab and are cursed by God for doing so. Elimelech and his two sons, one of whom was Ruth's husband, die there. In following her mother-in-law to Bethlehem, Ruth is reversing her husband's family's actions, turning to Yahweh and Israel rather than away from God and the land. Her mother-in-law, Naomi, then successfully carries out a plan to have Ruth marry a man named Boaz, a relative of Elimelech, who purchases the late man's land. When Ruth bears a son, the family line continues anew, even though it had seemed doomed with the death of Elimelech and his sons. Ruth is therefore the agent through whom the family manages to reproduce itself and retain its land after the curse in Moab. For these reasons, Raitiqa calls Ruth a 'redeemer of the land', and 
she turns to the subject of the vanua to ask how Fijian land can be redeemed of its 'sickness'.

She writes in English of 'vanua sickness', a literal translation of the Fijian term mate ni vanua, which denotes the punishment that results from breaking a taboo. The punishment is generated spiritually but manifests materially in such afflictions as illness, death, barrenness and failure to prosper. 'The whole concept of vanua sickness is that its cause is always related to the land,' Raitiqa writes.

There is a sense of mystery about it. What type of effect will occur, who will be affected, when it is going to appear are all parts of the mystery. One thing which is certain to be affected is the land (2003:103; see also Raitiqa 2000).

Thus the land itself, and the people who inhabit it by God's design-in other words, the vanua in both of its senses-suffer when taboos are broken. To explain how such sickness functions, Raitiqa turns to the term mana, which is often associated with effective action in Oceanic religious practice. And here, with mana, is where she makes a distinctive theological claim: that women can be linked directly to the mana by which the land is blessed with life and prosperity. Through Ruth, Raitiqa writes, 'God healed this family and their land as a whole' (2003:105). Thus although the vanua itself is not gendered in Raitiqa's description, women can 'redeem' it, realigning it with God's plans. She concludes her chapter by comparing Ruth with Jesus Christ, whom she calls 'the ultimate redeemer of the land' and 'the true mana' (2003:106). ${ }^{1}$ 
THE FEMININE FACE OF THE LAND: THE WORK OF ILAITIA SEVATI

\section{TUWERE}

At least two Fijian Methodist theologians have described the vanua as having distinctly feminine aspects. One is the late Paula Niukula, husband of one of the authors cited above (Sainimere Niukula) and president of the Methodist Church in Fiji from 1984 to 1986. In an English-language book compiling several essays originally published in Fijian, Niukula writes that indigenous Fijians' relationship to the land is like an indestructible bond between a mother and a child (P. Niukula 1994:30-31). The other theologian is Ilaitia Sevati Tuwere, who was the principal of the ecumenical Pacific Theological College in Suva (1982-88) and, like Niukula, served a term as president of the Methodist Church in Fiji (1996-98). Tuwere earned his doctorate from the Melbourne College of Divinity in 1992 with a dissertation titled 'Making Sense of Vanua (Land) in the Fijian Context: A Theological Exploration'. It was revised and published as a book in 2002, Vanua: Towards a Fijian Theology of Place. In this article, I confine my analysis to the book.

The book is divided into four parts: a general introductory section titled 'Birth', and three sections on the theology of the vanua titled 'Face', 'Mana', and 'Ear'. These three parts focus respectively on God's emplaced presence, God's power, and the need to listen and respect silence. In the introductory section, Tuwere foreshadows feminine themes to emerge more fully later in the book. For example, he quotes a villager from Wailevu saying that 'Land for me ... is like a mother,' and writes that 'the land ... is Mother Earth and therefore should not be exploited for selfish gains' (2002:35, 50; on the universalisation of the figure of 'Mother Earth', see Gill 1987). He notes the linguistic connection between 'land' and 'womb' or 'placenta' in many Oceanic languages (as do several of the non-Fijian 
authors in Weavings); although such a link does not exist in the Fijian language, he observes that Fijian men sometimes plant trees where their child's umbilical cord is buried, marking a foundational connection between a human life and a specific piece of land (2002:36, 93; see also Tuwere 2007:80). He also relates a creation story in which the daughter of an androgynous ancestral god offends it by disobeying its orders and serving her children plantains before offering them to the god. (The daughter, it must be noted, had a brother with whom she shared a collective identity; they were both called Tomaniivi. The female Tomaniivi's children were twins, a boy and a girl, who were also sea snakes. In this way, each of the first generations of this line of ancestral spirits featured male and female sides which were inseparably joined.) In giving her children the fruit, she handed the part attached to the stalk to her son and an outer portion to her daughter. 'This is why men are the principal actors in ceremonies and rituals while women remain at the periphery,' Tuwere explains, but he adds that women are 'important and significant for the well-being of the vanua. Through [them], the land maintains its fertility and so enables it to prosper' (2002:48-49; see also Sahlins' [1985:97] classic discussion of divine kingship in which he observes how Fijian chiefs, when being installed in their positions, undergo a 'metamorphosis [that] is the essential power of woman: transformation of a natural force, at once creative and destructive, into cultural substance'). In addition, he states that all chiefs are considered to be descended from the female side described in the myth. Accordingly, the present patriarchal order in indigenous Fiji-in which women are often marginalised in public ritual and the feminine is generally subordinated to the masculine-stands in tension both with Christian creation and Fijian origin mythology as Tuwere interprets them. 
In the book's second section, 'Face', Tuwere writes directly on the topic of the gender of the land. Referring to Genesis' description of the first man being made from dust, he writes that 'man's origin is in a piece of earth. His bond with the earth belongs to his essential being. The earth is his mother. He comes out of her womb' (2002:97). This position becomes most fully elaborated in the fifth chapter of the book, titled 'Feminine Face of the Land', in which Tuwere draws on sources including the feminist theologian Rosemary Radford Ruether and the apocryphal Wisdom of Solomon (which refers to wisdom in feminine terms, e.g., 'Wisdom reacheth from one end to another mightily: and sweetly doth she order all things'; Wisdom of Solomon 8:1). In this chapter, Tuwere makes two remarkable claims challenging deeply held indigenous Fijian Methodist beliefs. First, he argues that to imagine God as a dominant male figure, as many Fijian Methodists do, is un-Christian. Indeed, he writes that 'to hold an image of God as predominantly male or female is fundamentally idolatrous' (2002:113). Rather, he writes, God is an integrated combination of male and female, as in the Fijian myth of the androgynous god and its descendants. Second, he argues that the Fijian term and concept vakaturaga needs to be understood in newly gendered ways. Vaka- is an adjectival prefix, and turaga means 'chief', 'gentleman', or, when addressing God, 'Lord'; thus vakaturaga can be translated as 'chiefly', with connotations of respect, generosity, and propriety. As Tuwere notes, 'The expression idealises all that is good and honorable in life' (2002:110). No other expression laminates Fijian patriarchal values with male subjects as forcefully as (being) vakaturaga: ultimately, to be really good is to be a particular kind of male. But Tuwere attempts a radical reversal: he argues that 'Vakaturaga can be described as a maternal virtue in patriarchal clothing,' because being vakaturaga means being 'kind, caring and 
loving ... ready to forgive and forget, honest and humble' (2002:110). Such characteristics do not match with the vanua's political ideal of 'fighting for survival, conquering and settling' (2002:107).

I do not wish to defend stereotypes of the feminine as necessarily maternal, nor the maternal as necessarily non-combative. I do, however, want to point out that Tuwere-here, as elsewhere in his work (see Tomlinson 2010:752)—challenges dominant indigenous Fijian values in an attempt to portray a greater, synthetic truth which, for him, is a distinctly Christian one and not a distinctly male one. Tuwere, like many indigenous Fijian authors and speakers, treats the vanua as the ground of identity. As a theologian (and drawing partly on the work of another theologian, Walter Brueggemann) he articulates an understanding of God as necessarily connected to land. Some of Tuwere's statements about the vanua are as rhapsodic as any conservative politician's. For example, he writes that the vanua constitutes 'a way of life from time immemorial and bears the hopes, cries, dreams, values, joys, anxieties, silence and religions of a people' (2002:69). In writing about the feminine face of the land, however, Tuwere puts forth an argument that would disturb many Fijian ethno-nationalists: the vanua's patriarchal aspects and tendencies make it both less Christian and less authentically Fijian than it should be, and the masculine ideal of chiefliness is based on feminine values.

In the final sections of the book, 'Mana' and 'Ear', Tuwere does not pay as much attention to the feminine as he did earlier. He refers once to 'mother vanua', and asserts that non-Fijian men are 'less guilty' than indigenous Fijian men of taking a dismissive view of women's social roles (he mentions a common Fijian male opinion that women 'will finally end up in the kitchen' (2002:149, 198); cf. Trnka (2008) on Indo-Fijian women's perceptions of the moral value of their work). He also poses a fundamental 
question: 'What forces, cultural or otherwise, operate in villages and communities to concentrate the power to a few and to push others to the periphery of the poor and the powerless?' (2002:200). Anthropologically, the most compelling answer is that the modern ideology of the vanua itself does this: in portraying land as a gift from a stereotypically masculine God, to be ruled over by male chiefs, devotion to the vanua helps perpetuate the unequal social relationships that Tuwere decries. ${ }^{2}$ But Tuwere's project is theological and not anthropological. When arguing in an indicative mode, he is describing divine plans and not human ones, and when speaking of human actions he is arguing in a subjunctive mode for what ought to be the case, not what is. ${ }^{3}$

Tuwere is a man who ascended to the presidency of his church. He has the liberty to write and speak in provocative ways because he has risen so far; there is no career ceiling above him. What, then, might be the view of someone with a different position within the system-someone who has struggled firsthand with gender discrimination? And how might such a perspective sharpen scholarly understandings of the potential as well as the limits of theology in reshaping society?

\section{VANUA AS MALE: THE EXPERIENCES OF TIMA}

The Methodist Church in Fiji is facing two significant practical challenges at the moment. The first is that the Church has generally stood in opposition to the military-dominated government which took power in 2006. The Church's leadership opposed Voreqe Bainimarama's coup and his government's attempts to legitimise itself. As a result Bainimarama had various Methodist leaders arrested and cancelled or severely curtailed their annual conferences beginning in 2009 . The second challenge is the Church's declining membership. In 2007, the church had 289,923 members, 
but by 2012 the number had dropped to 197,226. In short, Methodists—for so long a dominant social and political force in indigenous Fiji-have become politically defensive while losing members, although they are still the largest religious denomination in the country. ${ }^{4}$

This sociopolitical context shaped an interview I conducted with a female Methodist minister, Tima, in Suva in February 2009. (Because of the sensitive nature of her story, I have given her a pseudonym.) She was unusual in several respects. First, the overwhelming majority of Methodist ministers are men, not women. Second, Tima came from a mixed-heritage background and spoke Fijian, Rotuman, and English well enough to preach in each. She also knew some Fiji Hindi, and had spent some time assisting a minister in the Church's Indian Division. Third, although an ordained minister, she was critical of the Methodist Church, but also determined not to leave it.

Early in our interview, when I asked about her career, Tima noted that when the Church appointed her to a Fijian circuit outside Suva in the late 1990s,

that was the first time they ever had a female minister in the circuit. I was the-well, more like I was a person they put there ... on a test trial, to see if women can handle it. And I suppose I was able to handle it my first year, that's why they started putting women into the Fijian circuit. ${ }^{5}$

By 'putting women into the circuit', she meant that she was assigned to a regular Church circuit and not given a special appointment such as a school or hospital chaplaincy. In general, however, she noted that 'the gender issue ... is very much alive. We have accepted women in the 
constitution of the Church to be coworkers, but in ... reality that is not happening. ${ }^{6}$

Tima's confidence in her calling led her into conflict with senior men, both during her student days at the Methodists' Davuilevu Theological College and during her ministerial work. She offered a vivid account of the early days of her appointment to Rotuma, the Polynesian island in Fijis far north:

Things are different there, y'know? The vanua is powerful, but at the same time they respect the Church. When I went to [circuit name], the vanua was overriding the Church, and I made my stand, the first meeting I had with them, with the vanua. I said to them, 'The Church and the vanua work together. That's how I see it. The Church will not overstep the vanua and the vanua will not overstep the Church. Anything to do with the Church, the vanua must respect it. Anything that has to do with the vanua, the Church will respect it—only if it is right. But if it is not right, the Church will supersede. Well that, I tell you, Matt, the elders of the land looked at me, and they must have said, if the walls could have echoed what was in their minds, the walls may have said to me, 'Oh, the-who's this little rat trying to tell us how to do things here?' Oh, yeah, I saw it, and I, I pretended like I didn't see anything, anywhere, I just kept on telling them in the meeting, the church meeting and [with] the vanua. ${ }^{7}$

In this excerpt, Tima presents the Church and the vanua as essentially separate, which is not a controversial statement in itself. Many conservative Methodist men would agree that each institution has its own path to follow, although the paths are closely aligned and headed in the same direction. 
But she goes a step further and declares that the Church has the authority to 'supersede' when the vanua goes astray.

During the interview she referred elliptically to an event in which she apparently ordered that a male chief, who was a relative on her father's side, be expelled from his position in the church. His offense was not specified. As she explained, she had

disciplined him and stripped him from his preaching appointments and from the position as tuirara, senior circuit steward. And ... everything went smoothly. There was no-y'know, people were angry, but there was no fighting or, y'know, that we had to end up to the police station or anything of that sort.

So her statement that the Church can overrule the vanua has to be interpreted in terms of an existing conflict, one in which she is claiming a measure of victory.

As described above, in Tuwere's theology the double meaning of vanua as both land and people is central. People cannot be disentangled from the land and the land cannot be disentangled from people. But this conjunction of place and person, presented positively by Tuwere, is a source of difficulty for Tima. Related to a chief who is harming the Church, she needs to expel him, but in doing so, she might suffer supernatural retribution. Tima said

We believe that the land also have [sic] its mana, and my mom was afraid because I was born here, and ... she knows how strongminded I am, and she thought what I did was wrong, like y'know I was just accusing the chief for nothing. 
This statement resonates with Raitiqa's description of vanua sickness.

My grandma used to say ... if the chiefs are right, and if the people try to go against the chiefs, they [the people] don't last. They don't last. So that ... that's the reason why my mom was afraid that ... maybe the chief was right and I was wrong.

Tima urged her mother to pray for her, asking that God grant her wisdom, and also warned her, 'don't interfere'.

The relationship between the Methodist Church and the chiefs and vanua is always complex and potentially rivalrous (Tomlinson 2009b). Indeed, later in the interview, Tima said,

Recently, I spoke to one talatala qase [superintendent minister] who said some of the young ministers come running to them, asking them for advice because the chiefs are overriding them in the circuit. Now what does that tell me, or tell us, of ministers today? They are scared. And they shouldn't be. You ... are serving one [God] who is above everything else.

In the case described above, the conflict was probably intensified because Tima is a woman. 'I questioned God, when I came back,' she recalled.

"Why me? Why me?" All these menfolks that had gone before me. Y'know, it would have been easier for a man to tell another man, y'know, "Hey mate, y'know, this, this, this, this" [i.e., criticised the chief in person for his bad behaviour]. But they never did that, I 
don't think they ever did that, that's why he continued what he did. And then here comes along a very ... junior, and a female, y'know, and just cleaned the mess up and then she get[s] kicked on her butt.

Tima then enrolled at Davuilevu Theological College for the Bachelor of Divinity degree, writing a thesis on the rebuilding of the temple in the Book of Haggai, and encountering more opposition from older men. Considering how all of the steps in her development as a Church authority had been marked by conflict, I asked Tima if she had ever considered leaving Methodism. Her answer was blunt:

I will never leave the Church, the Methodist Church.... I believe this is where God has placed me, and for me to move out—what Church in this world doesn't have problems? Problems are everywhere. We can't run away from it. But we can make a difference, probably a little difference, by speaking out, voicing out what needs to be done.

Regarding faith and conflict, Lamin Sanneh has written that 'Faith is not a demilitarized zone.... It is life's battlefront of encounter, risk, struggle, suffering, choice, grace, and deliverance' (Sanneh 2003:56). He is writing in a general way of whether or not one believes in God, but his words stick well to Tima's story. She is evidently driven by a strong sense of what God wants her to do, and yet working within the Church-as she feels she must do, and wants to do-partly undercuts her efforts. Whereas Tuwere presents non-combativeness as a 'maternal' value, Tima's identity as a female minister evidently makes her need to fight harder than the men to accomplish her purposes. 
In light of Fijian Methodism's patriarchal tendencies, Tima's story, while engrossing, is not especially surprising: a younger woman criticising and disciplining older men is an obvious point of conflict. And yet this story is an illuminating counterpoint to Tuwere's theology of the feminine face of the land. For Tuwere, Christianity's universalism opens up the possibility of reconciliation of all sorts: reconciliation of male and female in the vanua and in the figure of God, and also political reconciliation in post-coup Fiji. For Tima, however, reconciliation might not be fully possible. Recall how she informed the elders in Rotuma that when there is a conflict, the Church must prevail. And, in a telling conclusion to the interview, she mentioned a particular compliment she has received:

I don't believe in shouting in the meetings. I don't believe in that. When I have something that I'm passionate about, and I wanna put across, I normally get on my knees and cry to God, ask God for that right moment, the spirit to prepare ... the hearts of the people that I'm going to speak [to], 'Give me the words'-because I'm not a person of words. I like to sit and observe. 'Give me the words, prepare the atmosphere, and let your words fall.' I believe in that. But ... everyone-most of my colleagues do tell me, even my qases [seniors/superintendents] and my principal, they have said-and I do not deny it, because I know it for a fact-that I am a strong woman. I know that. A lot of pastors who worked with me have also said it, y'know? Elderly, matured, and good workers in the field. They've always said, y'know, 'When we look at you, we see a woman, we see a female. But when you speak and when you do your work, it's like a man.' [Laughs.] I'm very humbled by it, and 
sometimes I get sort of ashamed, but if anything [is] for the glory of God, then let it be.

By being a fighter and speaking boldly, Tima almost becomes categorically male. This observation from her coworkers is apparently meant as a compliment, and Tima's ambiguous answer-'I'm very humbled by it, and sometimes I get sort of ashamed'-points toward an interpretive thicket much denser and darker than Tuwere's writings on the feminine face of the land. But her determination to be heard raises fresh questions about the potential political impact of theology. Which understanding of the vanua has greater transformative potential for Fijian society: Tuwere's call to reimagine the feminine side of land and divinity through theology married to Fijian myth, or Tima's insistence that devotion to the church means that the vanua should always be subordinate, even, paradoxically, to the patriarchal and land-sacralising Christianity of Fijian Methodism?

\section{CONCLUSION}

At the beginning of this article, I posed the question of what is at stake when scholars speak of land in gendered terms. It might seem that, in attempting to offer an answer, I have come to a dissatisfying conclusion: everything is at stake, but little is likely to change. Tuwere's arguments about the feminine face of the land are radical, but the experience of Tima shows that the vanua's patriarchal tendencies endure. Such tendencies challenge efforts to reimagine what the land is and to rethink its nature as both a divine gift and integrally human place. Lest this be read as a cynical conclusion, I want to emphasise the modest point that writing and talking about the vanua is a compelling project for Methodists in Fiji at this historical moment. For the theologians discussed at length here, the vanua 
is a key focal point for representing and understanding divine interactions with humanity. Its gendered aspects, however, lead these theologians to come to different conclusions about how Christianity and the land ultimately do—or do not—come together.

Their visions must ultimately be understood as hopeful ones.

Raitiqa offers an understanding of women as Christlike bearers of mana for the land; Tuwere focuses on the feminine in order to cultivate a universal Christianity with indigenous Fijian roots; Tima, undaunted by opposition, tries to achieve change from within the Church. In this sense, each of them achieves a theology that treats its subject 'not only as science of faith but also as science of hope, which seeks to realise change and transformation through critique and new perspectives' (Schüssler Fiorenza 2011:19; cf. Miyazaki 2004).

In this spirit, I would like to give Tima the final word. Above, I quoted her justification for staying and working within the Methodist Church: 'Problems are everywhere. We can't run away from it. But we can make a difference, probably a little difference, by speaking out, voicing out what needs to be done'. And then she added: '

It may not happen immediately, but in—who knows, maybe [in a] few years down the line, then it might bring some light to the Church after all. But I don't see, I have never seen myself as a loser, giving up too easily. I'm a fighter.

\section{ACKNOWLEDGMENTS}

I am grateful to Tima for her insights and for allowing me to quote from the interview in which she discusses such personal matters. I also wish to thank Jacqueline Ryle, Andrew Thornley, Jan Rensel, Alan Howard, and the editors and reviewers of this issue for their help and advice. Research 
was funded by a Discovery Project grant from the Australian Research Council (DP0878736), and an initial version of this paper was presented at the 'Gender and Person in Oceania' workshop at the Australian National University in October 2011. All errors are my own.

\section{REFERENCES}

ADAMS, W.R. and F.A. SALAMONE (eds), Anthropology and Theology: Gods, Icons, and God-talk. Lanham, MD: University Press of America.

BLOM, I., K. HAGEMANN and C. HALL (eds), Gendered Nations: Nationalisms and Gender Order in the Long Nineteenth Century, Oxford: Berg

CHURCHWARD, C.M. 1998. Rotuman-English Dictionary. In E.K. Inia, S. Arntsen, H. Schmidt, J. Rensel, and A. Howard (eds), A New Rotuman Dictionary, pp. 172-363. Suva: Institute of Pacific Studies, University of the South Pacific.

COSTELLO-OLSSON, K. 2003. A prayer for women in conflict in Fiji. In L. Johnson and J.A. Filemoni-Tofaeono (eds), Weavings: Women doing Theology in Oceania, pp. 183-84. Suva: Weavers, SPATS, and IPS at the University of the South Pacific.

DEGEI, S.B. 2007. The challenge to Fijian Methodism—-the vanua, identity, ethnicity and change. Master of Social Sciences thesis, University of Waikato, Hamilton, New Zealand.

ENGELKE, M. and J. ROBBINS (eds). 2010. Global Christianity, Global Critique. South Atlantic Quarterly 109(4).

FOSTER R.J. (ed.). Nation Making: Emergent Identities in Postcolonial Melanesia, Ann Arbor: University of Michigan Press. 
GILL, S.D. 1987. Mother Earth: An American story. Chicago: University of Chicago Press.

HAGEMANN, K. 2000. A valorous Volk family: the nation, the military, and the gender order in Prussia in the time of the anti-Napoleonic Wars, 1806-15. In I. Blom, K. Hagemann and C. Hall (eds), Gendered Nations: Nationalisms and Gender Order in the Long Nineteenth Century, pp. 179-205. Oxford: Berg.

HALAPUA, W. 2003. Tradition, Lotu and Militarism in Fiji. Lautoka: Fiji Institute of Applied Studies.

HALAPUA, W. 2008. Waves of God's Embrace: Sacred Perspectives from the Ocean. London: Canterbury Press Norwich.

HEINZ, D. 1993. The Sabbath in Fiji as guerrilla theatre. Journal of the American Academy of Religion 61: 415-42.

HERMANN E. (ed.), Changing Contexts, Shifting Meanings:

Transformations of Cultural Traditions in Oceania, Honolulu: University of Hawai'i Press.

HOWARD, A. 1963. Land, activity systems, and decision-making models in Rotuma. Ethnology 2: 407-40.

INIA, E.K., S. ARNTSEN, H. SCHMIDT, J. RENSEL, and A. HOWARD (eds), A New Rotuman Dictionary. Suva: Institute of Pacific Studies, University of the South Pacific.

JOHNSON, L. 2003. 'Weaving the mat' of Pacific women's theology: a case study in women's theological method. In L. Johnson and J.A. Filemoni-Tofaeono (eds), Weavings: Women doing Theology in Oceania, pp. 10-22. Suva: Weavers, SPATS, and IPS at the University of the South Pacific. 
JOHNSON, L. and J.A. FILEMONI-TOFAEONO (eds). 2003. Weavings: Women doing Theology in Oceania. Suva: Weavers, SPATS, and IPS at the University of the South Pacific.

KAPLAN, M. 1995. Blood on the grass and dogs will speak: ritual politics and the nation in independent Fiji. In R.J. Foster (ed.), Nation Making: Emergent Identities in Postcolonial Melanesia, pp. 95-125. Ann Arbor: University of Michigan Press.

KELLY, J.D. 2011. Shanti and mana: the loss and recovery of culture under postcolonial conditions in Fiji. In E. Hermann (ed.), Changing Contexts, Shifting Meanings: Transformations of Cultural Traditions in Oceania, pp. 235-49. Honolulu: University of Hawai'i Press.

KELLY, J.D. and M. KAPLAN. 2001. Represented Communities: Fiji and World Decolonization. Chicago: University of Chicago Press.

LOANAKADAVU, N. 2012. Dwindling numbers. Fiji Times Online, 30 August. Online: http://www.fijitimes.com/story.aspx?id=210477, accessed 3 September 2012.

MANOA, P. 2010. Redeeming hinterland. Pacific Journal of Theology 43: 65-86.

McDOUGALL, D. 2011. Church, company, committee, chief: emergent collectivities in rural Solomon Islands. In M. Patterson and M. Macintyre (eds), Managing Modernity in the Western Pacific, pp. 121-46. St. Lucia: University of Queensland Press.

MEO, I. 2003. Asserting women's dignity in a patriarchal world. In L. Johnson and J.A. Filemoni-Tofaeono (eds), Weavings: Women doing Theology in Oceania, pp. 150-60. Suva: Weavers, SPATS, and IPS at the University of the South Pacific.

MEO, L. 2012. Women and theological education: Its significance in the 21st century and beyond. Pacific Journal of Theology 47: 42-51. 
METHODIST CHURCH IN FIJI AND ROTUMA. 1984. Ai vola ni yavu ni vakatulewa ni Lotu Wesele e Viti kei Rotuma / The Constitution of the Methodist Church in Fiji and Rotuma. Suva: Methodist Church in Fiji and Rotuma.

MILBANK, J. 2006. Theology and Social Theory: Beyond Secular Reason, [2 $2^{\text {nd }}$ ed. $]$. Malden, MA: Blackwell.

MIYAZAKI, H. 2004. The Method of Hope: Anthropology, Philosophy, and Fijian Knowledge. Stanford: Stanford University Press.

NIUKULA, P. 1994. The Three Pillars: The Triple Aspect of Fijian Society. Suva: Christian Writing Project.

NIUKULA, S. 2003. A Fijian woman's faith journey at the interface of gospel and culture. In L. Johnson and J.A. Filemoni-Tofaeono (eds), Weavings: Women doing Theology in Oceania, pp. 204-13. Suva: Weavers, SPATS, and IPS at the University of the South Pacific. PATTERSON, M. and M. MACINTYRE (eds), Managing Modernity in the Western Pacific. St. Lucia: University of Queensland Press PRIEST, R.J. 2000. Christian theology, sin, and anthropology. In W.R. Adams and F.A. Salamone (eds), Anthropology and Theology: Gods, Icons, and God-talk, pp. 59-75. Lanham, MD: University Press of America.

RAITIQA, L. 2000. Jesus: Healer of vanua sickness and mana of the vanua.

M.Th. thesis, Suva: Pacific Theological College.

RAITIQA, L. 2003. Ruth, redeemer of the land. In L. Johnson and J.A. Filemoni-Tofaeono (eds), Weavings: Women doing Theology in Oceania, pp. 99-107. Suva: Weavers, SPATS, and IPS at the University of the South Pacific.

RAMASWAMY, S. 2001. Maps and mother goddesses in modern India. Imago Mundi 53: 97-114. 
RAVUVU, A. 1983. Vaka i taukei: The Fijian Way of Life. Suva: Institute of Pacific Studies, University of the South Pacific.

ROBBINS, J. 2006. Anthropology and theology: an awkward relationship? Anthropological Quarterly 79: 285-94.

ROBBINS, J. and M. ENGELKE. 2010. Introduction. In M. Engelke and J. Robbins (eds), Global Christianity, Global Critique. South Atlantic Quarterly 109(4): 623-31.

RYLE, J. 2001. My God, my land: interwoven paths of Christianity and Tradition in Fiji. Ph.D. dissertation, London: School of Oriental and African Studies, University of London.

RYLE, J. 2010. My God, My Land: Interwoven Paths of Christianity and Tradition in Fiji. Farnham, Surrey, UK: Ashgate.

SAHLINS, M. 1985. Islands of History. Chicago: University of Chicago Press.

SAMATE, 'A.F. 2011. The challenge and contribution of gender to theological hermeneutics in Oceania. Pacific Journal of Theology 46: 55-94.

SANNEH, L. 2003. Whose Religion is Christianity? The Gospel Beyond the West. Grand Rapids, MI: William B. Eerdmans.

SCHÜSSLER-FIORENZA, E. 2011. Transforming Vision: Explorations in Feminist The*logy. Minneapolis: Fortress Press.

SORONAKADAVU, M. 2003. The traditional role of Fijian women, with reference to Christian justice. In L. Johnson and J.A. FilemoniTofaeono (eds), Weavings: Women doing Theology in Oceania, pp. 161-64. Suva: Weavers, SPATS, and IPS at the University of the South Pacific.

SOVAKI, M. 2003. Paradise: turmoil and rebirth. In L. Johnson and J.A. Filemoni-Tofaeono (eds), Weavings: Women doing theology in 
Oceania, pp. 181-182. Suva: Weavers, SPATS, and IPS at the University of the South Pacific.

TEAIWA, T. 2000. Fijian nationalism—is there such a thing? Wansolwara, June, 13.

THOMLINSON, M. 2006. Retheorizing mana: Bible translation and discourse of loss in Fiji. Oceania 76: 173-85.

2009a. Efficacy, truth, and silence: language ideologies in Fijian Christian conversions. Comparative Studies in Society and History 51: 64-90.

2009b. In God's Image: The Metaculture of Fijian Christianity. Berkeley: University of California Press.

2010. Compelling replication: Genesis 1:26, John 3:16, and Biblical politics in Fiji. Journal of the Royal Anthropological Institute 16: 743-60.

TRNKA, S. 2008. State of Suffering: Political Violence and Community Survival in Fiji. Ithaca, NY: Cornell University Press.

TUBANAVAU-SALABULA, L. 1996. The effect of environmental degradation on women. Pacific Journal of Theology 15: 62-64.

TUWERE, I.S. 1992. Making sense of vanua (land) in the Fijian context: a theological exploration. Ph.D. thesis, Melbourne: Melbourne College of Divinity.

TUWERE, I.S. 2002. Vanua: Towards a Fijian Theology of Place. Suva and Auckland: Institute of Pacific Studies at the University of the South Pacific and College of St. John the Evangelist.

2007. Land: a Fijian perspective. In M.-T. Wacker and E.M. Wainwright (eds), Land Conflicts, Land Utopias, pp. 79-86. London: SCM Press.

WACKER, M.-T. and E.M. WAINWRIGHT (eds), Land Conflicts, Land Utopias, London: SCM Press 


\section{NOTES}

${ }^{1}$ On first mentioning mana, Raitiqa translates it as 'blessing'; she then writes that it is 'power, an unseen positive power with a protective element. One can possess it after God bestows blessing' (2003:103, 107n2). For an analysis of how Christian missionary translations affected changing conceptions of mana in Fiji, see Tomlinson (2006, 2009a). John Kelly suggests that Fijian mana has developed a masculine aspect counterposed to feminine (or androgynous) Indo-Fijian shanti, 'a conception of religious peace and well-being' (Kelly 2011:236), a provocative argument but one I cannot take up here. See also Kaplan (1995:110-111) for a description of an Indo-Fijian mystic who publicised his prophecy for 'Fiji Fatherland' and 'India Motherland of the world'.

${ }^{2}$ One can also ask how different institutions elicit particular kinds of responsible collectivities. McDougall (2011) analyses how a synod of the Solomon Islands Uniting Church on Ranongga Island invoked and mobilised groups such as extended families, villages, and the Church's Women's Fellowship, whereas a legal dispute over logging pushed Ranonggans to act as 'tribal', matrilineal, land-owning collectives. McDougall observes that women had more possibilities to act in public, responsible ways at the Church synod than they did in the legal dispute. On women's ability to be public actors within Fijian Methodism, see Tomlinson (2009b:211n.8).

${ }^{3} \mathrm{~A}$ theologian who seems to both draw on and reject Tuwere's model of land and divinity is the Anglican bishop Winston Halapua, who is of Tongan heritage. Like Tuwere, he turns to the natural world to understand God, but-perhaps in a veiled criticism of Fijian Methodists who have promoted land-centred theologies_he writes, 'We, as people of Oceania ... speak 
not as people of the land but people who have been nurtured by the vastness of the ocean and the huge importance in human relationships of life-giving space.' He develops a theology he calls theomoana (moana is a term for 'ocean' in many Oceanic languages), explaining, 'The use of [the term] "moana" is gender-free and inclusive and with theo is a new way of expressing the dynamic being and nature of God' (2008:54, 92). Despite the intriguing parallels and tensions with Tuwere's work, however, Halapua does not cite or discuss it.

${ }^{4}$ The figure for 2007 comes from www.statsfiji.gov.fj (accessed 3 September 2012) and the figure for 2012 comes from Loanakadavu 2012. Statistics from different sources do not always harmonise.

${ }^{5}$ To streamline the presentation in this article, I do not include my own utterances like 'mm' or ' $\mathrm{hm}$ ' when quoting from the interview. I do, however, present Tima's voice with only light editing, with deleted material indicated by ellipses, and explanations and corrections in brackets. Like most speakers, she occasionally falters and searches for the right phrase, remembering, considering and summarising all at once. As a reader of a draft version of this article pointed out, this runs the risk of making her expressions look less articulate next to Tuwere's polished prose. While acknowledging this risk, I have chosen not to smooth out her speech. It might hit bumps and take detours but it arrives at elegant stations.

${ }^{6}$ The Church's constitution states that 'Men and women are both eligible' to become ministers, but also reserves the ordained position of deaconess for women (Methodist Church in Fiji and Rotuma 1984:7). Lesila Raitiqa, whose work is discussed in the first part of the article, is a deaconess. ${ }^{7}$ Rotuma is linguistically and culturally distinct from Fiji, but Methodists in Rotuma are part of the national church organisation (the Methodist Church 
in Fiji and Rotuma) and the Rotuman term hanua, cognate with vanua, also means both 'land, country, place; native land or place, home' as well as people belonging to a particular place (Churchward 1998:216; Alan Howard, personal communication, 15 May 2014). In this article, I am not attempting to theorise Rotuman understandings of hanua, but rather observing that Tima used the Fijian term vanua in its standard senses to describe the situation she encountered in Rotuma. For a discussion of different Rotuman concepts of hanua in relation to land tenure, see Howard (1963). 